\title{
TONGKAT ALI PLANTS OF EURYCOMA LONGIFOLIA AND STEMA TUBEROSA STIMULATE SEXUAL AROUSAL IN DOMESTIC COCKS
}

\section{Jaya Vejayan ${ }^{1 a^{*}}$ Yasmin Amira Che Yahya ${ }^{2 a}$, Srikumar Chakravarthi ${ }^{3 b}$, Rupbansraaj Bathmanathan ${ }^{4 a}$, Halijah Ibrahim $^{5 c}$ and Aida Yun ${ }^{6 d}$}

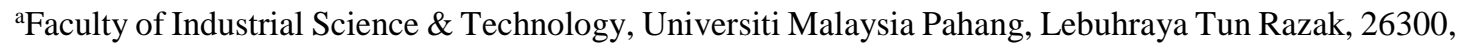
Gambang, Kuantan, Pahang Darul Makmur, MALAYSIA. Email: jayavejayan@ump.edu.my ${ }^{1}$; yasminamirah92@gmail.com² ${ }^{2}$ rupbansraaj@gmail.com ${ }^{4}$

${ }^{\mathrm{b}}$ Faculty of Medicine, Biomedical Sciences and Nursing, MAHSA University, Jalan SP2, Bandar Saujana Putra, 42610 Jenjarom Selangor, MALAYSIA. Email: srikumar@mahsa.edu.my ${ }^{3}$

${ }^{\mathrm{c} I n s t i t u t e}$ of Biological Sciences, University of Malaya, 50603 Kuala Lumpur, MALAYSIA. Email: ihalijah@um.edu.my ${ }^{5}$

dUbat Tradisional Orang Asli, Dataran Sungai Perak Sebelah Utara, North-South Expressway, Kampung Menora, 33000 Kuala Kangsar, Perak Darul Ridzuan, MALAYSIA. Email: nayajev@hotmail.com ${ }^{6}$ Corresponding author: jayavejayan@ump.edu.my

Received: $13^{\text {th }}$ Jun $2019 \quad$ Accepted: $8^{\text {th }}$ Oct $2019 \quad$ Published: $29^{\text {th }}$ Feb 2020 DOI: https://doi.org/10.22452/mjs.vol39no1.1

\begin{abstract}
This study compared the aphrodisiac ability of Tongkat Ali Merah (red type) or Stema tuberosa to Tongkat Ali Putih (white type) or E. longifolia. Fowls dosed orally with capsule containing E. longifolia and S. tuberosa respectively for 30 days followed by determining the efficacy by evaluating their sexual mating behavior parameters, testosterone blood level and histology of testicular tissue. Safety parameters included biochemical levels and histology of the liver. Both types of Tongkat Ali shown increases in testosterone levels $(7.7 \pm 0.59 \mathrm{nmol} / \mathrm{L}$ and $6.25 \pm 0.70$ $\mathrm{nmol} / \mathrm{L}$ and $4.08 \pm 0.85 \mathrm{nmol} / \mathrm{L} ;$ E. longifolia, S. tuberosa and control fowls, respectively) as well as testicular histology showing seminiferous tubules with increased cellularity with no evidence of inflammation or fibrosis compared to the control to indicate as testosterone boosters. All biochemical parameters tested shown to be within the control values except for alanine aminotransferase of E. longifolia i.e. $23.50 \pm 6.36 \mathrm{u} / \mathrm{L}$ (control $=8.00 \pm 2.94 \mathrm{u} / \mathrm{L}$ ). Additionally, some moderate tissue changes (focal areas of congestion of central vein and periportal scattered inflammation) were visible for the liver taken from E. longifolia treated fowls. S. tuberosa found without any untoward effects. Tongkat Ali Merah hereby been confirmed to boost testosterone in fowls although not as effective as Tongkat Ali Putih.
\end{abstract}

ABSTRAK Kajian ini memperbandingkan keupayaan afrodisiak Tongkat Ali Merah atau Stema tuberosa dengan Tongkat Ali Putih atau Eurycoma longifolia. Unggas disuap dengan kapsul yang mengandungi E. longifolia dan S. tuberosa selama 30 hari bagi mengetahui keberkesanannya dengan menguji tingkah laku seksual mereka, paras darah testosteron dan histologi tisu testis. Parameter keselamatan yang diuji termasuk tahap biokimia dan histologi hati. Kedua-dua jenis Tongkat Ali menunjukkan kenaikan paras testosteron $(7.7 \pm 0.59 \mathrm{nmol} / \mathrm{L}$ dan $6.25 \pm 0.70 \mathrm{nmol} / \mathrm{L}$ dan $4.08 \pm 0.85 \mathrm{nmol} /$ L; bagi E. longifolia, S. tuberosa serta unggahan kawalan, dalam urutan yang diberikan dan juga histologi testikular yang menunjukkan tubulus seminiferous dengan peningkatan selular tanpa apa-apa kesan keradangan atau fibrosis berbanding dengan kawalan iaitu membuktikan peningkatkan pengeluaran testosteron pada sel berkenaan. Semua parameter biokimia yang diuji menunjukkan pada persekitaran nilai kawalan yang juga diuji kecuali alanine aminotransferase bagi $E$. 
longifolia iaitu dengan peningkatan ketara, $23.50 \pm 6.36 \mathrm{u} / \mathrm{L}$ (kawalan $=8.00 \pm 2.94$ u / L). Selain itu, ada beberapa perubahan yang tidak diingini kepada tisu hati tetapi adalah dengan sederhana kesannya (kawasan tumpuan kesesakan vena pusat dan keradangan bertaburan periportal) bagi unggas dirawat dengan E. longifolia. S. tuberosa pula didapati tiada sebarang kesan yang tidak diingini sama sekali. Tongkat Ali Merah dengan ini disahkan dapat juga meningkatkan paras testosteron dalam unggas walaupun tidaklah setanding seperti Tongkat Ali Putih.

Keywords: Testosterone, Libido, Herbal, Sex, Chicken

\section{INTRODUCTION}

Tongkat Ali is known worldwide as an aphrodisiac plant. Not known to many is that the name is commonly applied to at least three types of plants in Malaysia i.e. Eurycoma longifolia, Stema tuberosa and Polyalthia bullata. The keyword, Tongkat Ali, is extremely popular with thousands of products to appear in the internet search if attempted. Many of the products available in the worldwide market been described merely as Tongkat Ali either at the product brand or their ingredient. Sales of the products are lucrative and mostly done online. Nowadays, western world is increasingly reliant on herbal medication (Garcia-Alvarez et al., 2014; Smith et al., 2015). Previously some doubts of the authenticity of the
Tongkat Ali products have already been highlighted whereby almost half of the products tested for two markers were found negative for the presence of the markers (Vejayan et al., 2018).

There are at least five plants using the synonym Tongkat Ali with three most common ones; E longifolia, $S$. tuberosa and $P$. bullata. These plants are pronounced as Tongkat Ali by indigenous and local Malay people in Malaysia with each distinctly known as Tongkat Ali Putih (white), Tongkat Ali Merah (red) and Tongkat Ali Hitam (black), respectively based on the colour of their root (Figure 1) (Kuo et al., 2004). The most popular of the three Tongkat Ali is Eurycoma longilofia Jack, commonly been used as herbal medicine worldwide (Mahmoud and Noor, 2013).

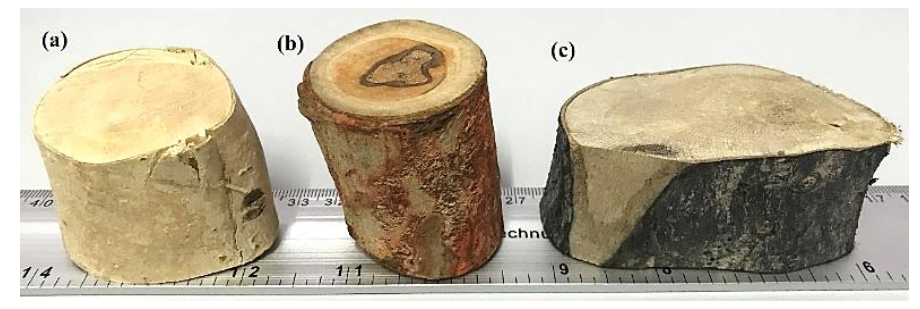

Figure 1. The cross section of roots from (a) E. longifolia (Tongkat Ali Putih), (b) $S$. tuberosa (Tongkat Ali Merah) and (c) P. bullata (Tongkat Ali Hitam). Insert: a ruler shown measurement in inches.

The aphrodisiac properties of $E$. longifolia have been extensively studied in vitro, in vivo and clinically (Ang et al., 2000; Bhat and Karim, 2010; Mohamed et al., 2015; Rehman et al., 2016; Scarano et al., 2006; Tambi et al., 2012). E. longifolia become a popular herbal medicine in Asia due to its high aphrodisiac properties. Many products have been developed based on 
E. longifolia and commercialized either in the capsule form, chips form or in the pre-mix coffee. Malaysian plants such as E. longifolia, S. tuberosa and $P$. bullata are claimed to have aphrodisiac properties and have been used in Malay traditional medicine. The aphrodisiac property of these plants is only a claim and has not been scientifically proven except for E. longifolia (Ang et al., 2000; Bhat and Karim, 2010; Mohamed et al., 2015; Rehman et al., 2016; Scarano et al., 2006; Tambi et al., 2012).

S. tuberosa is currently experiencing some discrepancies related to its scientific name. It is sometimes mentioned as Jackia ornata or Jackiopsis ornata (Family: Rubiaceae) (Abugabr Elhag et al., 2019). In this report the red variety root Tongkat Ali will be referred simply as Stema tuberosa. Among the three types, S. tuberosa or Tongkat Ali Merah has been claimed to be the most sorted Tongkat Ali by revisiting customers. Unfortunately, no scientific information was available on this plant.

In considering the availability of more than one type of plants under the synonym of Tongkat Ali to be used in manufacturing of aphrodisiac products ideally a study to compare efficacy and safety of E. longifolia and S. tuberosa been carried out.

\section{MATERIAL AND METHODS}

\subsection{Animals selection}

The male chicken or roosters used in this study were healthy Red Jungle Fowl (Gallus gallus). A total of 12 fowls used with four for each 3 groups (control, E. longifolia and $S$. tuberosa). All the roosters selected were aged between 26 - 28 weeks before their fertility peaks which was between 30 and 40 weeks of age. The average weight of fowls initially was about 1.25-2.0 kg. Animal ethics approval obtained UMPIACUC/2018/01.

\subsection{Capsule preparation}

Tongkat Ali roots obtained from reliable indigenous people living in the village of Kampung Orang Asli Bukit Cermin, Perak, Malaysia (GPS: $\left.4^{\circ} 45^{\prime} 48.2^{\prime \prime} \mathrm{N} \mathrm{100}{ }^{\circ} 58^{\prime} 13.3^{\prime \prime E}\right)$. Once the quality of $E$. longifolia was authenticated for the existence of eurycomanone (chemical marker) as well as that of protein Marker A as described by Vejayan et al. (2018), a conventional basic capsule marker was used to formulate the capsule. The " 0 " sized capsules were filled with pulverised and sieved (sieve pore size: 200 mesh) root chips without additives or excipient. Similarly, S. tuberosa root powder filled capsules were prepared. The dosage of $E$. longifolia and $S$. tuberosa used was $12 \mathrm{mg}$ (calculated based on the average weight of the chicken) per capsule. Any empty space within the capsule were occupied with powdered chicken feed (corn bran).

\subsection{Dosage method}

The control (capsule containing chicken feed only), E. longifolia and $S$. tuberosa groups of fowl (4 each) were given one capsule in the morning and another in the evening ("bis in die", b.d.) daily for 30 days. The orogastric procedure involved placing the capsule into a forced wide open beak followed immediately by supplying with a straw small quantity of drinking water and consequently shutting tightly the beak. Momentarily the chicken was noticed to swallow willingly the capsule. An inspection of the mouth cavity done 
after sometime to ensure dosing completed successfully.

\section{$2.4 \quad$ Sexual mating behaviour}

There a few indicators that will be used as parameters in the observation of sexual mating i.e. frequency of wing flapping, body-shake, crow and pecking (Leonard and Zanette, 1998). A rooster was placed for an hour with healthy hen age about a month after 30 days of dosing to record changes in mating behaviours and weight (initial, days 15 and 30).

\section{$2.5 \quad$ Blood collection}

After evaluating the roosters' sexual mating behaviour, the blood drawn from control and test subjects. A total of $5 \mathrm{ml}$ of blood collected from the rooster by slaughtering. The blood that drawn out after slaughtering collected by using a beaker. A syringe used to draw the blood collected and transferred into a vacutainer (obtained from Gribbles Pathology Diagnostic Laboratory, Malaysia). The blood samples collected and send to Gribbles Pathology Diagnostic Laboratory, Malaysia and tested on various biochemical parameters.

\subsection{Histology on testis and liver}

Testis and liver dissected out carefully and placed onto $5 \mathrm{ml}$ of $10 \%$ formalin overnight. The preparation and grading of the tissues are as done by Haleagrahara et al, 2009 and 2010. Briefly the tissues were sliced, and exposed to graded xylene, alcohol and then embedded in paraffin wax blocks.
Sections are taken at 5 microns using a Leica microtome on glass slides and stained with hematoxylin and eosin. The prepared slide analyzed under a light microscope (Nikon, Eclipse TS100) for inflammation, congestion, and grading for all the groups.

\subsection{Statistical analysis}

Data collected for the mating observations and biochemical parameters were evaluated by ANOVA from the Social Science (SPSS) version 20. Statistical significance of data was assessed by analysis of variance and differences were considered significant at $(\mathrm{p}<0.05)$. The least significance difference (LSD) test were used to compare the means.

\section{RESULTS AND DISCUSSIONS}

\subsection{Monitoring of body weight}

The fowls were weighed initially and on the $15^{\text {th }}$ and $30^{\text {th }}$ days. Over the $30^{\text {th }}$ day observations none of the four fowl in any group required to be excluded or replaced due to drastic weight lost. Instead, the results in Table 1 showed weight gains on the 15 day for all groups while only E. longifolia fowls showed weight gains beyond the 15 days. Previously it has been reported $E$. longifolia treated rats capable to have their laevator ani muscle increased in weight after dosing for 12 consecutive weeks (Ang and Cheang, 2001). While in men, E. longifolia increased the fat free mass, reduced body fat, and increased muscle strength and size (Hamzah and Yusof, 2003). 
Table 1. Weight of fowls during experiment

\begin{tabular}{lcccc}
\hline \multicolumn{1}{c}{ Fowls } & $\begin{array}{c}\text { Initial average } \\
\text { weight }(\mathbf{k g}) \pm \text { S.D }\end{array}$ & $\begin{array}{c}\text { Gain }(\mathbf{g m}) \pm \text { S.D in weight } \\
\text { to initial }\end{array}$ & $\begin{array}{c}\text { End average } \\
\text { weight }(\mathbf{k g}) \pm \text { S.D }\end{array}$ \\
\cline { 2 - 4 } & & Day 15 & Day 30 & \\
\hline Control & $2.025 \pm 0.22$ & $75 \pm 9.5$ & $0 \pm 0.0$ & $2.1 \pm 0.30$ \\
E. longifolia & $1.35 \pm 0.19$ & $50 \pm 2.5$ & $125.5 \pm 2.3$ & $1.53 \pm 0.27$ \\
S. tuberosa & $1.6 \pm 0.17$ & $50 \pm 1.7$ & $0 \pm 0.0$ & $1.65 \pm 0.16$ \\
\hline Result & &
\end{tabular}

Result showed the weight gain by the fowls during experiment, which $n=4$ fowls for each group and mean \pm standard deviation

\subsection{Sexual mating behaviour observation}

Table 2 compared the frequencies in the sexual mating behaviours of the fowls after being treated with $E$. longifolia and $S$. tuberosa. E. longifolia showed increases of sexual mating frequency compared to $S$. tuberosa and with both plants being higher than the control fowls for all type of behaviours. Overall, the results showed that $E$. longifolia give the highest frequency for all sexual mating behaviour.

Table 2. Summary of the sexual behaviour frequency observed

\begin{tabular}{cccc}
\hline $\begin{array}{c}\text { Types of Sexual } \\
\text { Behaviour }\end{array}$ & \multicolumn{3}{c}{ Sexual Frequency Observed } \\
\cline { 2 - 4 } & Control & E. longifolia & S. tuberosa \\
\hline Wing Flapping & $4.0 \pm 0.4$ & $6.0 \pm 0.5$ & $5.5 \pm 0.2$ \\
Body-shakes & $4.3 \pm 0.2$ & $7.3 \pm 0.4$ & $5.5 \pm 0.3$ \\
Crows & $3.5 \pm 0.3$ & $6.0 \pm 0.6$ & $5.2 \pm 0.4$ \\
Pecking & $3.0 \pm 0.0$ & $7.0 \pm 0.6$ & $4.5 \pm 0.3$ \\
\hline
\end{tabular}

Results were expressed as mean \pm SEM. The level of significance was taken at $p<0.05$ compared with the control, $\mathrm{n}=4$.

\subsection{Blood plasma level}

As shown in Table 3, testosterone for the E. longifolia, $7.70+0.59 \mathrm{nmol} / \mathrm{L}$ found almost twice the value of the control, $4.07 \pm 0.85$ $\mathrm{nmol} / \mathrm{L}$. Although not to the extent of $E$. longifolia, $S$. tuberosa also showed an elevation of testosterone levelwith no obvious increment of any of the biochemical parameters tested. Hence through this results $S$. tuberosa provided evidence of stimulating testosterone hormone within 30 days of dosing without any untoward circumstances. The capability of $E$. longifolia in stimulating this androgen hormone is well documented (Talbott,
2019). In some study on human, $E$. longifolia has been found to increase the serum testosterone level, treat erectile function disorder and improve sperm production problems (Hamdi et al., 2016). Besides that, most studies used rat to test $E$. longifolia as it is able to increase libido in male rats and decrease hesitation time for male rats toward female rats (Ho and Tan, 2011).

All the other biochemical parameters provided only slight reduction or elevation except for the ALT (alanine aminotransferase) indicators of E. longifolia. The value observed for the biochemical parameter of the ALT for E. longifolia of $23.50 \pm$ 
$6.36 \mathrm{u} / \mathrm{L}$ was markedly elevated, almost three-fold increase in comparison to the control value of only $8.00 \pm 2.94 \mathrm{u} / \mathrm{L}$. In human, ALT and AST (aspartate aminotransferase) are two indicators of liver damage with the former to be more specific to liver. Based on American Association for the Study of Liver Diseases (AASLD), ALT levels greater than 5 times the upper limit of the normal range suggests a potentially serious, active liver disease process (Kim et al, 2008). Therefore, result shown by E. longifolia treated fowls having approximately 3 times more ALT levels than the control may suggest potential liver damage however can only be ascertained clearly if investigated further for prolong or chronic use of more than 6 months. Interestingly, sub-chronic studies on rats treated with $E$. longifolia concentrations of up to $2000 \mathrm{mg} / \mathrm{kg}$ bodyweight for a period of 90 days shown have no significant blood chemistry (including ALT) and haematological parameters (Choudhary et al., 2012). Choudhary et al, treated the rats orally by gavage an aqueous extract E. longifolia once a day for 90 days.

Table 3. Biochemical parameters for both E. longifolia and S. tuberosa

\begin{tabular}{lccc}
\hline Biochemical parameters & Control & E. longifolia & S. tuberosa \\
\hline & & & \\
Testosterone (nmol/L) & $4.08 \pm 0.85$ & $7.70 \pm 0.59$ & $6.25 \pm 0.70$ \\
ALT (u/L) & $8.00 \pm 2.94$ & $23.50 \pm 6.36$ & $5.25 \pm 0.5$ \\
AST (u/L) & $312.67 \pm 49.80$ & $308.25 \pm 55.95$ & $232.75 \pm 21.58$ \\
GGT (u/L) & $22.00 \pm 3.51$ & $18.75 \pm 10.34$ & $23.50 \pm 4.20$ \\
Total Protein (g/L) & $50.75 \pm 2.99$ & $45.25 \pm 4.86$ & $40.75 \pm 3.86$ \\
Albumin/Globulin ratio (g/L) & $0.53 \pm 0.05$ & $0.63 \pm 0.17$ & $0.65 \pm 0.13$ \\
Total Bilirubin (umol/L) & $50.75 \pm 2.99$ & $47.25 \pm 2.5$ & $17.75 \pm 1.5$ \\
Urea (mmol/L) & $1.03 \pm 0.26$ & $1.10 \pm 0.36$ & $1.28 \pm 0.35$ \\
Creatinine (umol/l) & $12.75 \pm 0.96$ & $10.00 \pm 1.41$ & $17.50 \pm 6.45$ \\
Uric Acid (mmol/L) & $0.12 \pm 0.03$ & $0.13 \pm 0.01$ & $0.18 \pm 0.025$ \\
& & &
\end{tabular}

Data were expressed as mean \pm SEM. The level of significance was taken at $p<0.05$

\subsection{Histological profile of liver and testis}

The prepared slides were analyzed under a light microscope (Nikon, Eclipse TS100) for inflammation, congestion, and grading for all the groups. Photomicrographs were taken by Nikon 8.1 MP camera using Nikon Eclipse software.
Table 4 showed moderate changes on congestion of liver for EL2EL4 and with only mild changes for inflammation or necrosis of liver in comparison to controls. As for ST1ST4, the changes in liver were similar to EL group, with focal areas of necrosis and regeneration scattered through the parenchyma. Mild to moderate congestion was seen in all livers. 
Table 4. Histopathological evaluations of liver treated with E. longifolia and $S$. tuberosa

\begin{tabular}{cccc}
\hline Fowl & Inflammation & Necrosis & Congestion \\
\hline EL1 & 0 & 0 & 0 \\
EL2 & + & 0 & ++ \\
EL3 & + & + & ++ \\
EL4 & + & 0 & ++ \\
ST1 & + & + & + \\
ST2 & + & + & ++ \\
ST3 & + & 0 & + \\
ST4 & + & + & ++ \\
\hline
\end{tabular}

Keys: EL \& ST - rooster test fowls given E. longifolia and S. tuberosa containing capsules for 30 days. The histological scoring scale used was $0=$ no changes, $+=$ mild, $++=$ moderate,$+++=$ severe compared to control fowls .

As shown in Figure 2(a), for control rooster the liver showed normal architecture with normal central vein and well-spaced portal triads, no evidence of congestion. Hepatocytes and sinosoids appeared normal. While on Figure 2(b-c), EL4 and ST4, showed focal areas of congestion of central vein and periportal scattered inflammation, suggesting that perhaps the dosage administered was causing hepatic changes suggestive of drug metabolism, but not significant enough to cause necrosis or damage.
In summary, the liver tissues taken from fowls treated with $E$. longifolia provided outcome which was not severe based on its histopathological results alone. Nevertheless, in combining this results with the obvious elevation of ALT (Table 3) the severity to liver is questionable if the study been carried forward for a longer duration (i.e. 6-12 months) for E. longifolia. No such concerns existed for $S$. tuberosa as it provided positive results for histopathological liver grading and its corresponding biochemical markers (i.e. ALT, AST and GGT).

(a)

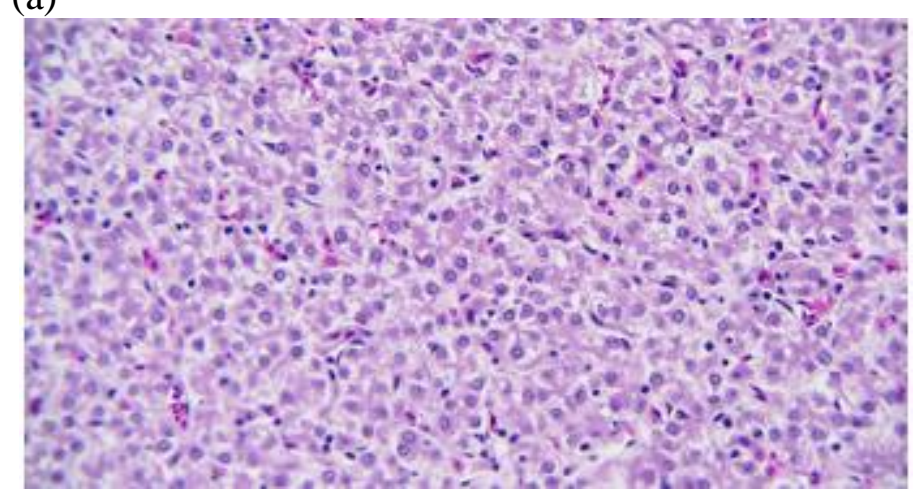


(b)

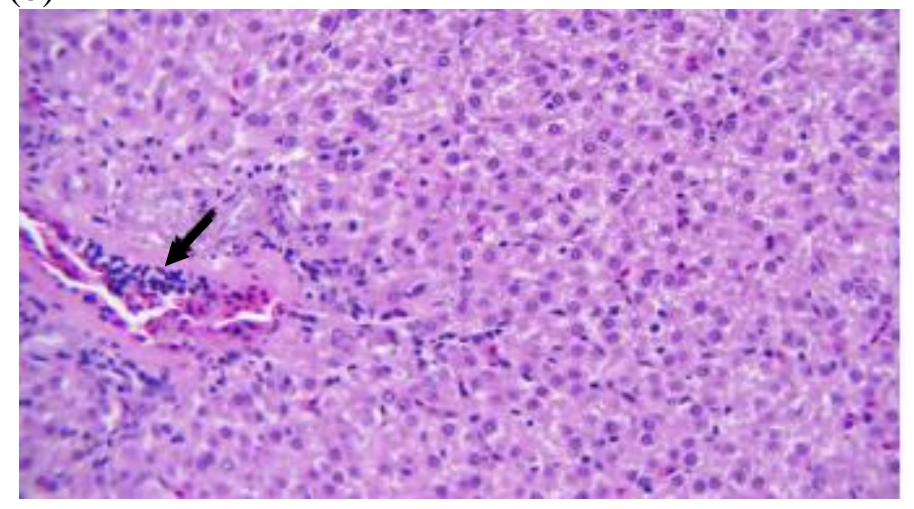

(c)

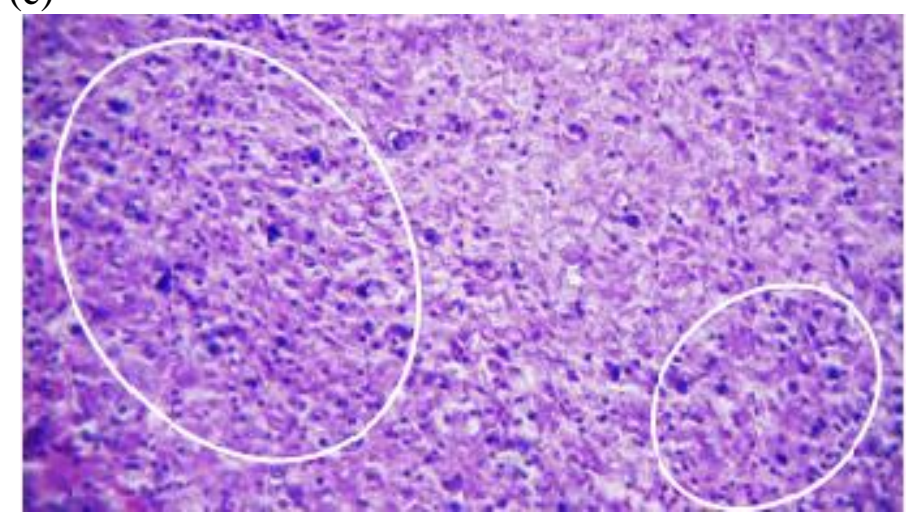

Figure 2: Photomicrograph of liver tissue, H\&E, 400X. Histology of liver showing normal (a), EL4 (b), showing periportal inflammation (arrow) and scattered diffuse inflammation and ST4 (c) group of fowls showing diffuse inflammation and areas of regenerative hepatocytes (circles).

Plants have been generally regarded as safe compared to synthetically sourced constituents as drugs (Di Lorenzo et al., 2015; Posadzki et al., 2013). Though that is the general understanding of herbal consumption but the wellbeing of liver has been of concern in recent years (Seeff, et al., 2015). E. longifolia safe consumption is questionable based on the elevation of ALT biochemical indicator and with moderate outcome for the liver histological grading. Shuid et al, 2011 (Shuid, et al., 2011) reported that the sub-acute oral intake (28 days) of $2400 \mathrm{mg} \mathrm{kg}^{-1}$ E. longifolia aqueous extract was hepatotoxic to rats. It is easily possible to provide reasoning for this safety concerns to be minor and negligible but as it is common for any herbal capsule to be taken twice a day continuously some caution is warranted for deterring liver failure. Personal communications with Malaysian indigenous people in Kampung Orang Asli Kampung Cermin described some of their long term customers decided to only consume one capsule once a day after some years. Such dosing regimen should also apply in elderly or patients with liver problems. E. longifolia use at low doses does not appear to cause any toxic effect on the pancreas over a period of more than a month (Hamoud and Qamar, 2013). E. longifolia is normally recommended to be administered to men at the dose of 200 $400 \mathrm{mg}$ daily (Shuid, et al., 2011). 
As shown in Figure 3(a), a segment of the testis showed numerous seminiferous tubules, sized at approximately 150-200 microns, showing adequate cellularity of spermatogonia, primary spermatocytes, secondary spermatocytes, spermatids and spermatozoa. There are scattered leydig cells. No evidence of inflammation or fibrosis. While on Figure 3(b-c), the testis of EL4 and ST4 fowls showed increased seminiferous tubules, sized at approximately 200-250 microns, which were larger than the control group. The tubules showed increased cellularity compared to the control, with increase in all cells spermatogonia, primary spermatocytes, secondary spermatocytes, spermatids and spermatozoa. The spermatogonia were prominent in the centre of the lumen with long tails and closely clustered together. No evidence of inflammation or fibrosis. This suggest that E. longifolia and S. tuberosa had direct stimulating effects on both the seminiferous tubules, and also the mitosis of the germ cells and also the maturation of the cells.

\section{Hence overall E. longifolia} shown as expected of its testosterone boosting capabilities similar to previous studies (Ang and Lee, 2002; Ang and Ngai, 2012; Tambi et al., 2012; Zanoli et al., 2012). Additionally, positive evaluations were attained of the mean frequency sexual mating behaviours and histology on testis of test fowls. Coincidentally histology of testicular tissues obtained from rats treated for 28 days with $E$. longifolia roots showed active germinal epithelium with successive stages of spermatogenesis and lumen of the seminiferous tubules were filled with spermatozoa in comparison to control (Mahmoud and Noor, 2013).

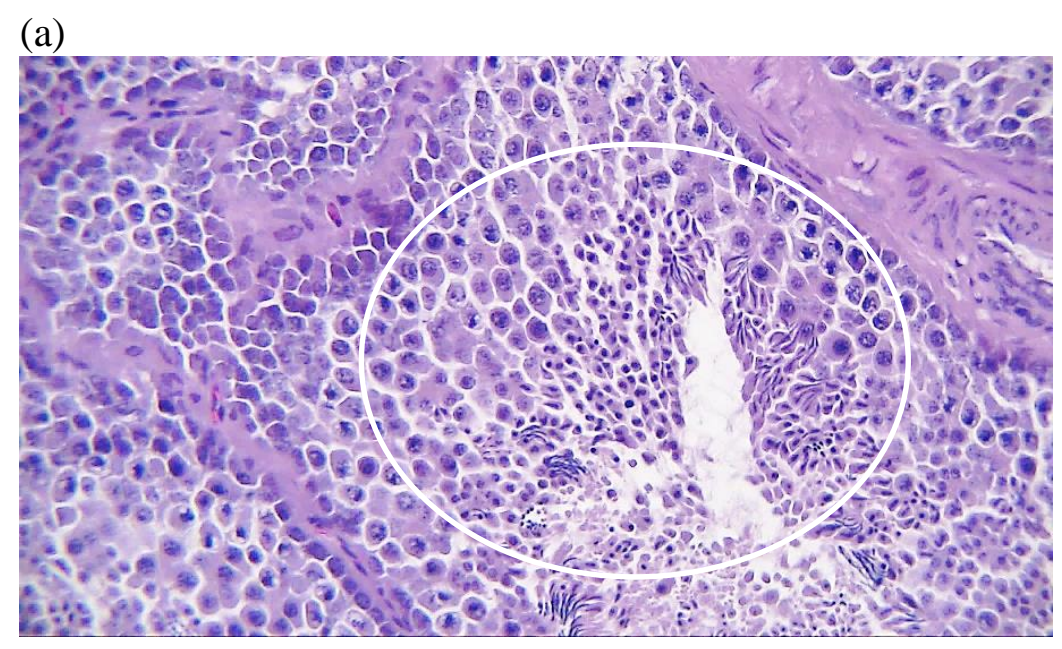


(b)

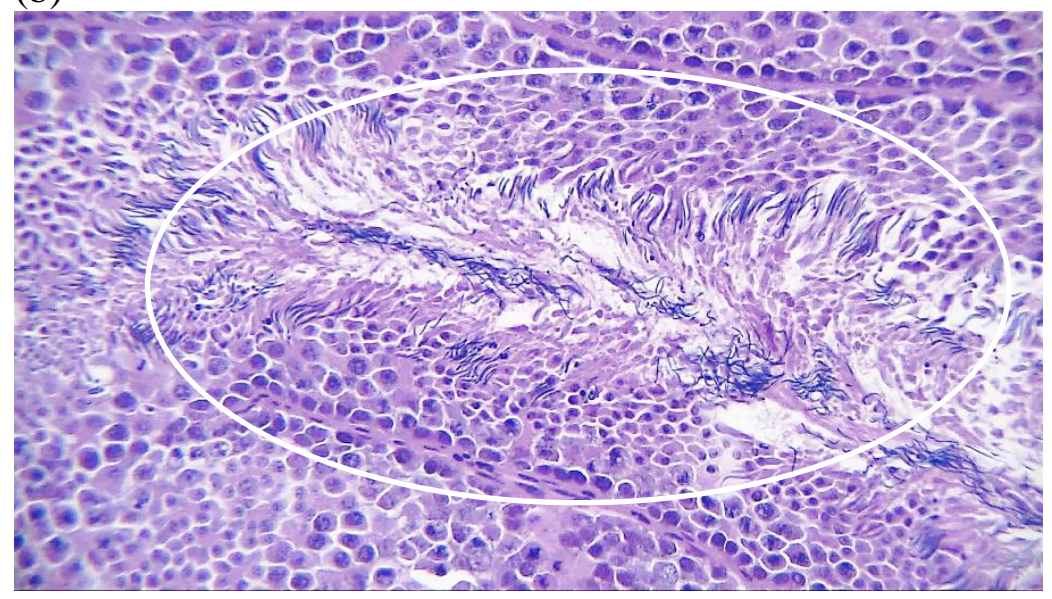

(c)

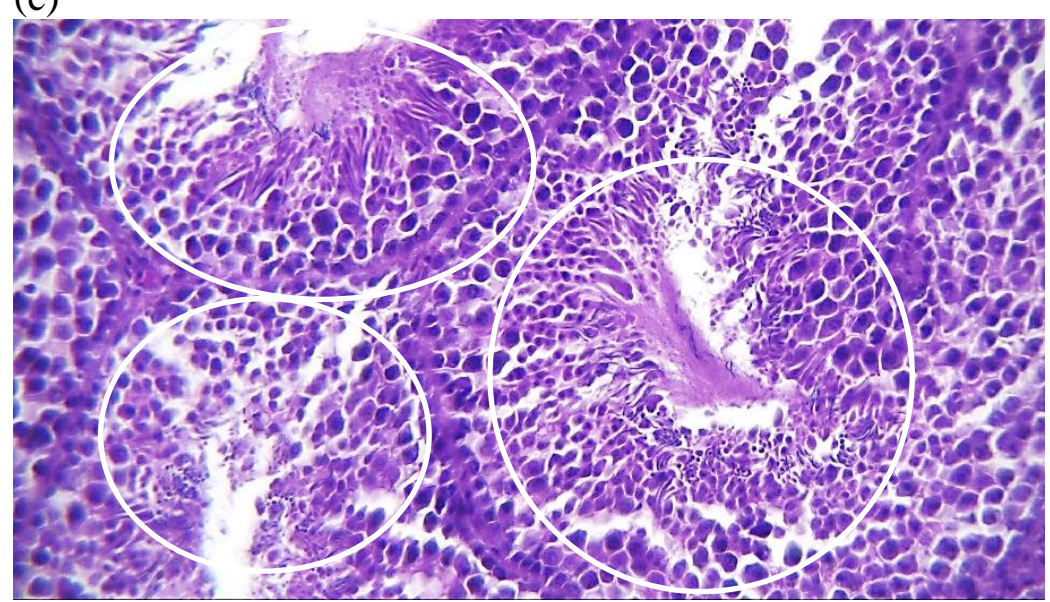

Figure 3. Photomicrograph of testis tissue, H\&E, 400X. Histology of testis showing normal (a) showing adequate proliferative activity of the cells, EL4 (b) and (c) ST4 group of fowls showing increased proliferation (both number and maturity) of all the types of cells in the seminiferous tubules including mature spermatozoa in EL4 and

ST4 groups, as in circles.

S. tuberosa, although not as potent an aphrodisiac as E. longifolia, showed sufficient results to substantiate its claim as being a testosterone booster. E. longifolia treated fowls shown an increase of approximately $90 \%$ testosterone concentration while $S$ tuberosa with approximately $55 \%$ increase in comparison to the untreated fowls i.e. $4.08 \mathrm{nmol} / \mathrm{L}$. Histology on the testis of test fowls dosed with $S$. tuberosa provided further evidence on the stimulation of specific region within the male reproductive organ. The total frequencies tabulated for the sexual mating behaviours (wing flapping, body-shakes, crows and pecking) for $S$. tuberosa (approximately 21 counts) were less convincing compared to $E$. longifolia (approximately 26 counts) but both were higher than control (approximately 15 counts). In the short duration of dosing been done, i.e. 30 days, both plants performed well as sexual stimulant with $E$. longifolia ranked above $S$. tuberosa.

\section{CONCLUSIONS}

Although E. longifolia showed higher efficacy indicators i.e. sexual mating behaviours, testosterone level and active testicular histology it is 
however marred by its safety related to elevate ALT and moderate damage to the liver as observed within 30 days of exposure. On the other hand, $S$. tuberosa is safer as compared to $E$. longifolia but it exhibited lesser aphrodisiac activity.

\section{ACKNOWLEDGEMENTS}

The study funded by Universiti Malaysia Pahang precommercialization grants with code of UIC170904 and postgraduate grant of PGRS1903203, partially by RDU180375 and MTUN external grant of UIC191201.

\section{REFERENCES}

Abugabr Elhag, HE., Naila, A., Ajit, A, Sulaiman, AZ., Ishak, WFW., Abd Aziz, B and Prasad, R., (2019). Optimization of protein yields in water extracts of Jackiopsis ornata roots by response surface methodology using microwave assisted extraction (MAE). In AIP Conference Proceedings (Vol. 2068, pp. 1-10). AIP. https://doi.org/10.1063/1.50893 54

Ang, HH. and Cheang, HS. (2001). Effects of Eurycoma longifolia Jack on laevator ani muscle in both uncastrated and Testosterone-Stimulated castrated intact male rats. Archives of pharmacal research 24(5): 437-440. https://link.springer.com/article /10.1007/BF02975191

Ang, HH. and Lee, KL. (2002). Effect of Eurycoma longifolia Jack on orientation activities in middle- aged male rats. Fundamental \& clinical pharmacology 16(6): 479-483. https://doi.org/10.1046/j.14728206.2002.00106.x

Ang, HH. and Ngai, TH. (2012). Aphrodisiac evaluation in noncopulator male rats after chronic administration of Eurycoma longifolia Jack. Fundamental \& Clinical Pharmacology 15(4): 265-268.

https://doi.org/10.1046/j.14728206.2001.00038.x

Ang, HH., Cheang, HS. and Yusof, APM. (2000). Effects of Eurycoma longifolia Jack (Tongkat Ali) on the initiation of sexual performance of inexperienced castrated male rats. Experimental Animals 49(1): 35-38. https://doi.org/10.1538/expani m.49.35

Bhat, R. and Karim, AA. 2010. Tongkat Ali (Eurycoma longifolia Jack): a review on its ethnobotany and pharmacological importance. Fitoterapia 81(7): 669-679. https://doi.org/10.1016/j.fitote. 2010.04.006

Choudhary, YK., Bommu, P., Ming, YK. and Zulkawi, NB. (2012). Acute, sub-acute, and subchronic 90-days toxicity of Eurycoma longifolia aqueous extract (Physta) in wistar rats. International Journal of Pharmacy and Pharmaceutical Sciences 4: 232238.https://www.academia.edu/ 4257843/ACUTE_SUB_ACUT E_AND_SUBCHRONIC_90DAYS_TOXICITY_OF_EUR YCOMA_LONGIFOLIA_AQ UEOUS_EXTRACT_PHYST A_IN_WISTAR_RATS_Resea rch_Article 
Di Lorenzo, C., Ceschi, A., Kupferschmidt, H., Lüde, S., De Souza Nascimento, E., Dos Santos, A., ... and Finglas. P. (2015). Adverse effects of plant food supplements and botanical preparations: a systematic review with critical evaluation of causality. British journal of clinical pharmacology 79(4): 578-592.

DOI:

10.1111/bcp.12519

Garcia-Alvarez, A. Egan, B., de Klein, S., Dima, L., Maggi, FM., Isoniemi,M., ... and Bruno. F. (2014). Usage of plant food supplements across six European countries: findings from the PlantLIBRA consumer survey. PloS one 9(3): e92265. https://doi.org/10.1371/journal. pone. 0092265

Haleagrahara, N., Jackie, T., Chakravarthi, S., Rao, M. and Kulur, A. (2010). Protective effect of Etlingera elatior (torch ginger) extract on lead acetateinduced hepatotoxicity in rats. The Journal of toxicological sciences 35(5): 663-671. https://www.termedia.pl/BASI

C-RESEARCH-Protectiveeffect-of-N-acetylcysteine-oncyclosporine-A-inducedchanges-in-lipidhydroperoxide-levels-andrenal-dysfunction-inrats, $19,12287,1,1 . h t m l$

Haleagrahara, N., Yee, TM., Chakravarthi, S. and Lee N. (2009). Protective effect of Nacetylcysteine on cyclosporine A-induced changes in lipid hydroperoxide levels and renal dysfunction in rats. Archives of Medical Science 5(1): 16-22. https://www.termedia.pl/BASC -RESEARCH-Protective effect-
of-N-acetylcysteine-on

cyclosporine-A-induced

changes-in-lipid-

hydroperoxide-levels-and-

renal-dysfunction-in-

rats, $19,12287,1,1 . h t m l$

Hamdi, AHA., Ming, LC. and Kassab. YW. (2016). A review on safety and efficacy of products containing Longifolia. Archives of Pharmacy Practice, 7(5): 39.

DOI: $10.4103 / 2045-$

080X.183036

Hamoud, HA. and Qamar, UA. (2013). Effect of Long-term use of Eurycoma Longifolia Jack on The Pancreas in rats: Histological Assessment. Regenerative research, 2(2): Special, 22-25. https://regres.tesma.org.my/pdf/ RR-201113-

007\%20R1\%20(4).pdf

Hamzah, S. and Yusof, A. (2003). The Ergogenic Effects of Eurycoma Longifolia Jack: A Pilot Study. Br J Sports Med, 37: 464-470. https://bjsm.bmj.com/content/3 $7 / 5 / 464$

Ho, CC. and Tan, HM. (2011). Rise of herbal and traditional medicine in erectile dysfunction management. Current urology reports, 12(6): 470-478. https://doi.org/10.1007/s11934011-0217-X

Kim, WR., Flamm, SL., Di Bisceglie, AM. and Bodenheimer Jr., HC. (2008). Serum Activity of Alanine Aminotransferase (ALT) as an Indicator of Health and Disease. Hepatology 47(4): 1363-1370. https://doi.org/10.1002/hep.221 09 
Kuo, PC., Damu, AG., Lee, KH. \& Wu, TS. (2004). Cytotoxic and antimalarial constituents from the roots of Eurycoma longifolia. Bioorganic \& medicinal chemistry 12(3): 537544.

https://doi.org/10.1016/j.bmc.2 003.11 .017

Leonard, ML. and Zanette, L. (1998). Female mate choice and male behaviour in domestic fowl. Animal Behaviour 56: 10991105.

https://doi.org/10.1006/anbe.19 98.0886

Mahmoud, ASF. and Noor, MM. (2013). Comparative study on the effect of Eurycoma longifolia and Smilax myosotiflora on male rats fertility. In AIP Conference Proceedings (Vol. 1571, No. 1, pp. 227-233). AIP. https://doi.org/10.1063/1.48586 59

Mohamed, AN., Vejayan, J. and Yusoff, MM. (2015). Review on Eurycoma longifolia pharmacological and phytochemical properties. Journal of Applied Sciences 15(6): 831 . DOI: 10.3923/jas.2015.831.844

Posadzki P., Watson, L. and Ernst, E. (2013). Herb-drug interactions: an overview of systematic reviews. Br J Clin Pharmacol 75: 603-18. DOI: $10.1111 / \mathrm{j} .1365-$ 2125.2012.04350.x

Rehman, S., Choe, K. and Yoo, H. (2016). Review on a traditional herbal medicine, Eurycoma longifolia Jack (Tongkat Ali): its traditional uses, chemistry, evidence-based pharmacology and toxicology. Molecules 21(3): 331. doi: $10.3390 /$ molecules 210303 31

Scarano, WR., Messias, AG., Oliva, SU., Klinefelter, GR., \& Kempinas, WG. (2006). Sexual behaviour, sperm quantity and quality after short-term streptozotocin-induced hyperglycaemia in rats. Int $\mathbf{J}$ Androl 29(4): 482-488. https://onlinelibrary.wiley.com/ doi/full/10.1111/j.13652605.2006.00682.x

Seeff, LB., Bonkovsky, HL., Navarro, VJ. and Wang, G. (2015). Herbal products and the liver: a review of adverse effects and mechanisms. Gastroenterology 148(3): 517-532. DOI: $10.1053 /$ j.gastro.2014.12.004

Shuid, AN., Siang, LK., Chin, TG., Muhammad, N., Mohamed, N. and Soelaiman, IN. (2011). Acute and subacute toxicity studies of Eurycoma longifolia in male rats. International Journal of Pharmacology, 7(5): 641-646. DOI: 10.3923/ijp.2011.641.646

Smith, T., Lynch, ME., Johnson, J., Kawa, K., Bauman, H. and Blumenthal, M. (2015). Herbal dietary supplement sales in US increase $6.8 \%$ in 2014. HerbalGram, 107: 52-59. http://cms.herbalgram.org/herb algram/issue107/hg107-mktrpt2014hmr.html

Talbott, MS. 2019. Chapter 63 - Human Performance and Sports Applications of Tongkat Ali 
(Eurycoma longifolia) edited by Bagchi, D., Nair. S and Sen, C.K. Nutrition and Enhanced Sports Performance: Muscle Building, Endurance and Strength, Second Edition. Elsevier. Pages 729-734. https://doi.org/10.1016/B978-012-813922-6.00063-1

Tambi, MIBM., Imran, MK. and Henkel, RR. (2012). Standardised water- soluble extract of Eurycoma longifolia, Tongkat ali, as testosterone booster for managing men with late- onset hypogonadism? Andrologia 44: 226-230. 10.1111/j.14390272.2011.0116 8. $\mathrm{X}$
Vejayan, J., Mohamed, AA., Zulkifli, AA., Yahya, YAC., Munir, N. and Yusoff, MM. (2018). Marker to authenticate Eurycoma longifolia (Tongkat Ali) containing aphrodisiac herbal products. Current Science, 115(5): 886-894. https://www.currentscience.ac.i n/Volumes/115/05/0886.pdf

Zanoli, P., Zavatti, M., Montanari, C. and Baraldi, M. (2012). Influence of Eurycoma longifolia on the copulatory activity of sexually sluggish and impotent male rats. Journal of ethnopharmacology, 126(2): 308-313. https://doi.org/10.1016/j.jep.20 09.08.021 